\title{
Malignant Esophageal Neoplasm by Topographic Region
}

National Cancer Institute

\section{Source}

National Cancer Institute. Malignant Esophageal Neoplasm by Topographic Region. NCI

Thesaurus. Code C7513.

Esophageal segments used primarily in pathology, and distinct from the anatomic segments used for clinical purposes. 